\title{
PEMANFAATAN ORGAN TUMBUHAN SEBAGAI OBAT YANG DIOLAH SECARA TRADISIONAL DI KECAMATAN KEBUN TEBU KABUPATEN LAMPUNG BARAT
}

\author{
Maulidiah $^{1}$, Ovi Prasetya Winandari ${ }^{1}$, Dwijowati Asih Saputri ${ }^{1}$ \\ ${ }^{1}$ Program Studi Pendidikan Biologi Fakultas Tarbiyah dan Keguruan Universitas \\ Islam Negeri Raden Intan Lampung
}

\begin{abstract}
The Use of Plant Organs as Medicines That are Traditionally Processed in Kebon Tebu, West Lampung.Traditional medicinal plants are ingredients or ingredients of natural ingredients derived from plants that have been used for generations based on experience. The use of plants as medicine has been done for a long time. Knowledge of medicinal plants is a national heritage based on experiences that have been passed down from generation to generation. Inheritance of knowledge about traditional medicine from generation to generation is the cause of the extinction of this knowledge. The knowledge possessed by traditional communities in the village is rarely written in written form, mostly only known by those who are old. While the younger generation, especially those who have integrated with modern life, are rarely concerned with the knowledge possessed by their people. This study aims to gather information from the public regarding the use of plant organs as traditionally treated drugs in Kebun Tebu District, West Lampung Regency and Make archives about the use of medicinal plants that can be utilized by the community of Kebun Tebu District, West Lampung Regency. this research is descriptive research using interview and observation methods. The results of the study found 42 types of medicinal plants which were divided into 25 families that were used by the community in Kebun Tebu District, West Lampung Regency as traditional medicine ingredients. Part of the medicinal plants used are roots, stems, leaves, rhizomes, tubers, flowers and fruit with various processing methods such as: boiled, grated, thin, crushed, squeezed, eaten and drunk directly, used directly, dropped, brewed and juiced.
\end{abstract}

Keywords : Medicinal Plants, Traditional Medicine

\begin{abstract}
Abstrak: Pemanfaatan Organ Tumbuhan Sebagai Obat Yang Diolah Secara Tradisional Di Kecamatan Kebun Tebu Kabupaten Lampung BaratTanaman obat tradisional adalah bahan atau ramuan bahan alam yang berasal dari tumbuhan yang secara turun-temurun telah digunakan untuk pengobatan berdasarkan pengalaman. Pemanfaatan tumbuhan sebagai obat sudah dilakukan sejak lama. Pengetahuan tentang tumbuhan obat, merupakan warisan bangsa yang berdasarkan pengalaman yang telah diwariskan secara turun temurun. Pewarisan pengetahuan mengenai obat tradisional secara turun temurun pada masyarakat menjadi penyebab punahnya pengetahuan tersebut. Pengetahuan yang dimiliki oleh masyarakat tradisional di kampung jarang yang dituangkan dalam bentuk tertulis, kebanyakan hanya diketahui oleh mereka yang sudah tua. Sedangkan generasi muda, terutama yang sudah berintegrasi dengan kehidupan modern, jarang yang peduli dengan pengetahuan yang dimiliki masyarakatnya. Penelitian ini bertujuan untuk Mengumpulkan informasi dari masyarakat mengenai pemanfaatan organ tumbuhan sebagai obat yang diolah secara tradisional di Kecamatan Kebun Tebu, Kabupaten Lampung Barat dan Membuat arsip tentang pemanfaatan tumbuhan obat yang dapat dimanfaatkan masyarakat Kecamatan Kebun Tebu, Kabupaten Lampung Barat. penelitian ini merupakan penelitian deskriftif menggunakan metode wawancara dan observasi. Hasil penelitian ditemukan 42 jenis tumbuhan obat yang terbagi ke dalam 25 famili yang dimanfaatkan masyarakat di Kecamatan Kebun Tebu Kabupaten Lampung Barat sebagai bahan obat tradisional. Bagian dari
\end{abstract}


tanaman obat yang dimanfaatkan yaitu akar, batang, daun, rimpang, umbi, bunga dan buah dengan cara pengolahan yang bervariasi seperti: direbus, diparut, mipis, ditumbuk, diremas, dimakan dan diminum langsung, digunakan langsung, diteteskan, diseduh dan dijus.

Kata Kunci : Obat Tradisional, Tanaman Obat

\section{PENDAHULUAN}

Indonesia merupakan negara kepulauan yang beriklim tropika yang memiliki banyak flora dan fauna. Dimana Indonesia juga adalah negara yang sangat banyak menyimpan keanekaragaman etnis yang mempunyai macam-macam pengetahuan tentang obat tradisional yang memakai bahanbahan dari tanaman yang tersebar di berbagai pulau besar dan kecil.

Tumbuhan obat adalah tanaman yang sebagian atau seluruhnya digunakan sebagai obat, bahan atau ramuan (Tjitrosoepomo, 2005). Pemanfaatan tanaman sebagai obat sudah dilakukan sejak lama. Upaya pemanfaatan tanaman sebagai obat tidak hanya dilakukan oleh masyarakat umum, tetapi juga dilakukan oleh pemerintah. Pengetahuan tentang tumbuhan obat merupakan warisan budaya dan bangsa yang berdasarkan pengalaman yang telah diwariskan secara turun-temurun, hal tersebut dianggap menjadi penyebab punahnya pengetahuan tersebut (Wardiah, 2015).

Ilmu yang dimiliki oleh masyarakat tradisional di kampung jarang yang dituangkan dalam bentuk tertulis, kebanyakan hanya diketahui oleh mereka yang sudah tua. Sedangkan generasi muda, terutama yang sudah berintegrasi dengan kehidupan modern kurang peduli dengan pengetahuan yang dimiliki masyarakat.

Tujuan dari penelitian ini adalah Mengumpulkan informasi dari masyarakat mengenai cara pemanfaatan organ tanaman sebagai obat yang diolah secara tradisional di Kecamatan Kebun Tebu, Kabupaten Lampung Barat.

\section{METODE}

Penelitian ini dilaksanakan pada bulan Mei 2018 di Kecamatan Kebun
Tebu Kabupaten Lampung Barat, Alat yang digunakan dalam penelitian ini adalah gunting stek/ pisau lipat, koran, karton, etiket gantung dan etiket tempel, penjepit/ sasak, selotip, plastik, benang, alkohol 70\%, galah, alat tulis, kamera, dan angket. Bahan penelitian yang diguanakan yaitu semua jenis tanaman obat yang dimanfaatkan oleh masyarakat Kecamatan Kebun Tebu Kabupaten Lampung Barat.

Penelitian ini dilakukan dengan menggunakan instrument atau alat pengumpulan data sebagai berikut: 1) wawancara yaitu dengan cara melakukan wawancara pada para tokoh masyarakat seperti kepala desa dan penduduk yang berada pada wilayah penelitian dengan cara mengambil $10 \%$ responden dari jumlah KK (Kepala Keluarga) setiap desa dengan menggunakan kuesioner yang telah disediakan (Arikunto, 2002). Untuk menghindari bias responden dipilih dari masyarakat yang tempat tinggalnya berjarak lebih dari 200 meter (Hurlbert, 1971). Rentan umur penduduk yang diwawancarai yaitu: a) 17-30 tahun dikategorikan usia muda, b) $>30-45$ tahun dikategorikan usia dewasa, c) >45-59 tahun dikategorikan usia paruh baya, d) >60 tahun dikategorikan usia tua. 2) berbagai penelitian khususnya yang ada hubungan dengan tumbuhan sebagai bahan obat tradisional.

Observasi, yaitu dengan cara melakukan pengamatan pada tumbuhan yang ada di daerah tempat penelitian yang selanjutnya dilakukan dokumentasi guna sebagai pembuktian kevalidan pada proses observasi, yang selanjutnya dipakai sebagai herbarium. 3) Studi Kepustakaan, dengan membaca dan mencatat karya tulis Data yang diperoleh ditabulasi dengan dianalisis secara deskriptif dengan pendekatan kuantitatif. 
HASIL

Berdasarkan penelitian yang telah dilakukan di Kecamatan Kebun Tebu Kabupaten Lampung Barat dengan metode wawancara dan observasi dengan masyarakat, diperoleh 42 jenis tanaman obat yang terbagi ke dalam 25 famili, yaitu Zingiberaceae, Asteraceae, Rubiaceae, Euphorbiaceae, Fabaceae,
Lamiaceae, Poaceae, Arecaceae, Piperaceae, Myrtaceae, Basellaceae, Lauraceae, Menispermaceae, Oxalidaceae, Annonaceae, Rutaceae, Mackinlayaceae, Thymelaeaceae, Acanthaceae, Muntingiaceae, Urticaceae, Campanulaceae, Xantrorrhoeaceae, Solanaceae,

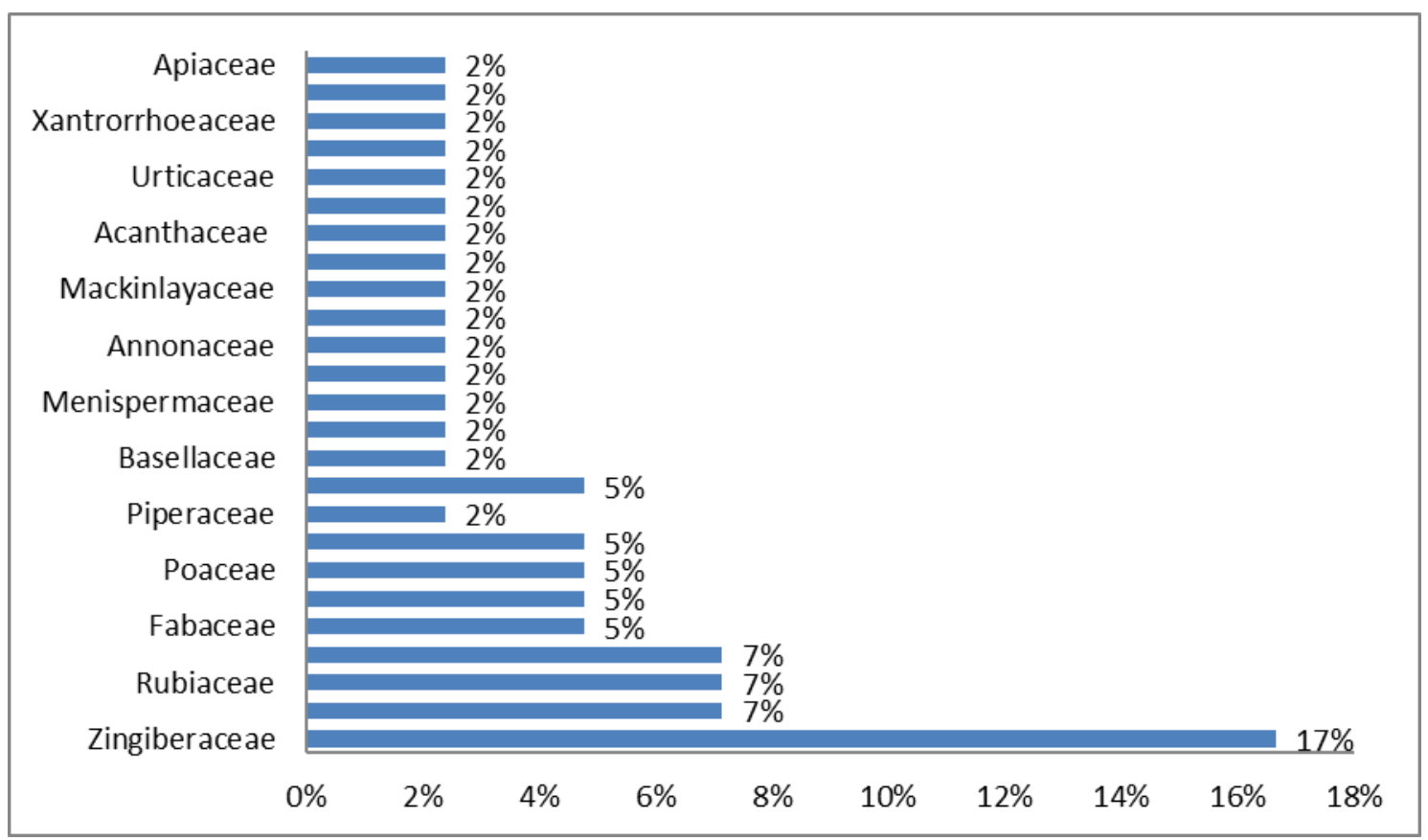

\section{Gambar 1. Jumlah Jenis Tanaman Berdasarkan Kelompok Famili Yang Digunakan Oleh Masyarakat Kecamatan Kebun Tebu Kabupaten Lampung Barat}

\section{PEMBAHASAN}

Pemanfaatan tanaman obat paling banyak terdapat pada famili Zingiberaceae. Berdasarkan hasil wawancara, jenis tanaman yang berasal dari famili tersebut sangat banyak dan mudah diperoleh serta dapat mengobati berbagai macam penyakit. Selain itu, famili Zingiberaceae merupakan kelompok tanaman obat yang paling banyak digunakan, hal ini disebabkan karena tanaman tersebut lebih mudah dibudidayakan dan dapat tumbuh di berbagai jenis tanah.

ditumbuk, ditempel, ditetes, dioles, ditambahkan garam, gula, cuka dan minyak kelapa. Pengolahan tanaman obat ini memang sederhana, namun
Telah berabad-abad manusia sudah mengenal tanaman sebagai penghasil bahan obat-obatan. Tanaman obat ini ternyata dapat meringankan rasa sakit, secara turuntemurun pengetahuan ini dipertahankan dan diwariskan (Pasorong, 2015). Tanaman obat merupakan jenis tanaman yang sebagian atau seluruh tanaman digunakan sebagai obat, bahan atau ramuan obat-obatan (Hamzari, 2008).

Tanaman obat ini digunakan sebagai obat luar dengan cara dibakar, jenis tanaman obat yang digunakan haruslah tepat. Setiap tanaman obat memiliki efek farmakologi yang sangat beragam, serta pemakaian yang salah 
dapat berakibat fatal (Siswanto, 2004).

Farmakologi adalah ilmu pengetahuan yang berhubungan dengan obat-obatan, yang memiliki keanekaragaman struktur kimia metabolit sekunder tinggi serta menjadi sumber senyawa obat yang tak terbatas. Metabolit sekunder adalah senyawa organik yang disintesis oleh tanaman dan merupakan sumber senyawa obat, digolongkan atas alkaloid, terpenoid, steroid, fenolik, flavonoid dan saponin (Saifudin, 2014).

Beberapa manfaat dari kandungan senyawa metabolit sekunder ini berpotensi sebagai antioksidan, antikanker, antiinflamasi, antimikroba, antidiabetes dan antitripanosoma (Gunawan, 2016). Kandungan senyawa metabolit sekunder ini dapat mengobati berbagai jenis penyakit berupa gangguan perut/perncernaan, penyakit kulit/luka/memar, gangguan otot, gangguan kepala, penyakit dalam, gangguan pernafasan, membersihkan darah/menetralkan darah, sakit gigi dan iritasi mata (Rahmiyani, 2015).

Bagian tanaman obat yang dimanfaatkan yaitu, akar, batang, daun, rimpang, buah, bunga dan umbi dengan pemanfaatan dan pengolahan yang bervariasi. Bagian tanaman yang paling banyak digunakan yaitu daun sekitar 49\%, rimpang 24\%, buah $16 \%$, batang $6 \%$, akar $3 \%$, umbi $2 \%$ dan yang paling jarang digunakan adalah bagian bunga hanya $1 \%$. penggunaan pada daun merupakan yang terbanyak dikarenakan perbedaan ketersediaan daun yang lebih banyak jika dibandingkan dengan bahan lainnya, seperti akar, buah, bunga dan batang. Juga terdapat keuntungan menggunakan daun sebagai obat karena serat pada daun lunak sehingga lebih mudah ketika diekstrak.

Masyarakat menganggap bahwa daun banyak mengandung obat dalam mengobati berbagai penyakit. Daun adalah bagian yang paling mudah diperoleh dan mudah diramu sebagai obat dibanding dengan kulit, akar dan batang. Selanjutnya masyarakat menilai bahwa daun dipercaya memiliki khasiat sebagai obat dibandingkan bagian tanaman obat lain. Hal ini, karena daun mengandung klorofil yang di dalamnya terdapat senyawa antioksidan, antiperadangan dan zat yang bersifat menyembuhkan penyakit (Mamahani, 2016).

Masyarakat di Kecamatan Kebun Tebu Kabupaten Lampung Barat mengolah tanaman obat dengan beberapa cara yakni direbus, diparut, mipis, ditumbuk, diremas, dimakan dan diminum langsung, digunakan langsung, diteteskan, diseduh dan dijus. Pengolahan tanaman obat yang sering dilakukan oleh masyarakat di Kecamatan Kebun Tebu Kabupaten Lampung Barat yaitu dengan cara direbus.

Upaya untuk menjaga keutuhan pengetahuan tentang cara pengolahan dan penggunaan tanaman obat tersebut aparat desa dan masyarakat di Kecamatan Kebun Tebu Kabupaten Lampung Barat mewajibkan disetiap pekarang rumah harus menanam tanaman obat atau yang sering dikenal dengan istilah TOGA (Tanaman Obat Keluarga) (Muhlisah, 2007).

Pengetahuan lokal masyarakat di kecamatan Kebun Tebu mengenai tanaman obat tradisional dan pengobatan tradisional lebih banyak diketahui berdasarkan pengalaman, komunikasi serta interaksi sosial masyarakat yang ada di sekitarnya. Yang palingutama hal-hal tentang pengetahuan diperoleh dari hasil komunikasi masyarakat sekitar ataupun dari keluarga sendiri. Sedangkan untuk informasi berdasarkan hasil bacaan dari buku sangat terbatas.

\section{KESIMPULAN}

Berdasarkan hasil penelitian dan pembahasan dapat disimpulkan bahwa masyarakat di Kecamatan Kebun Tebu Kabupaten Lampung Barat mengolah tumbuhan obat dengan beberapa cara yakni direbus, diparut, mipis, ditumbuk, diremas, dimakan 
dan diminum langsung, digunakan langsung, diteteskan, diseduh dan dijus.Untuk menjaga keutuhan pengetahuan tentang cara pengolahan dan penggunaan tumbuhan obat aparat desa

dan masyarakat di Kecamatan Kebun Tebu Kabupaten Lampung Barat mewajibkan disetiap pekarangan rumah harus menanam tanaman obat atau yang sering dikenal dengan istilah TOGA (Tanaman Obat Keluarga).

\section{SARAN}

Penelitian selanjutnya disarankan agar meneliti kandungan tanaman obat tersebut secara spesifik.

\section{DAFTAR PUSTAKA}

Arikunto, S. (2002). Manajemen Penelitian. jakarta: Rineka Cipta.

Gunawan, G., Chikmawati, T., Sobir, S., \& Sulistijorini, S. (2016). Fitokimia genus Baccaurea spp. Bioeksperimen: Jurnal Penelitian Biologi, 2(2), 96-110.

Hamzari, H. (2008). Identifikasi Tanaman Obat-obatan Yang Dimanfaatkan Oleh Masyarakat Sekitar Hutan Tabo-tabo. Jurnal Hutan dan Masyarakat, 3(2), 8206.

Hurlbert, S. H. (1971). The nonconcept of species diversity: a critique and alternative

parameters. Ecology, 52(4), 577586.

Mamahani, A. F. (2016). Etnobotani Tumbuhan Obat Masyarakat Subetnis Tonsawang

Kabupaten Minahasa Tenggara Provinsi Sulawesi Utara. Pharmachon, 5(2).

Muhlisah, f. (2007). Tanaman obat keluarga (TOGA). Jakarta: Penebar Swadaya.

Pasorong, Y. S., Tambaru, E., Umar, M. R., \& Masniawati, A. (2015). Identifikasi Tumbuhan Berkhasiat Obat dan Potensi Pemanfaatannya Pada Beberapa Desa di Sekitar
Gunung Sesean Kabupaten Toraja Utara. Universitas Hasanuddin. Makassar.

Rahmiyani, I. (2015). Inventarisasi dan skrining fitokimia tumbuhan obat berkhasiat antiinflamasi yang digunakan oleh masyarakat kampung naga. Jurnal Kesehatan Bakti Tunas Husada: Jurnal IImuilmu Keperawatan, Analis Kesehatan dan Farmasi, 13(1).

Saifudin, A. (2014). Senyawa alam metabolit sekunder. Yogyakarta: Deepublish.

Siswanto. (2004). Penanganan Hasil Panen Tanaman Obat Komersial. Jakarta: Penebar Swadaya.

Tjitrosoepomo, G. (2005). Taksonomi Tanaman obat-obatan. Yogyakarta: Gadjah Mada University Press.

Wardiah, W., Hasanuddin, H., \& Muthmainnah, M. (2015). Etnobotani Medis Masyarakat Kemukiman Pulo Breueh Selatan Kecamatan Pulo Aceh Kabupaten Aceh Besar. Jurnal EduBio Tropika, 3(1). 